\title{
Factors for Stock Markets to Avoid Big Falls During the Coronavirus Epidemic
}

\author{
Jiarui $\mathrm{Wu}$ \\ Nanjing Foreign Language School, Nanjing 210008, China \\ E-mail: grace_wu_1222@163.com

\begin{abstract}
COVID-19 affected the whole world. Millions of people were infected, and shops and factories are closed. WHO also listed the epidemic as public health emergency of international concern. The corona virus has led to big falls in economy. Many people are curious about how the virus affect the economy and why the stock market haven't fallen much as the GDP. The reasons for GDP falls are analyzed in this paper. Also, the author analyzes the factors which may affect the stock price and shows why the stock market haven't fallen much. The current statistics were added in this paper. Besides, the author analyzes the cases which were similar to COVID-19 such as the Spanish flu, Hong Kong flu, Asian flu and SARS. The author gives the statement upon the past and the current.
\end{abstract}

Keywords: COVID-19, GDP growth, stock market, epidemic

\section{INTRODUCTION}

2020 is a very special year when the COVID-19 influence the whole world. People stayed at home to keep apart from others to avoid being infected. Many firms and factories stopped work and the economy was hugely affected. People do not go outside as often as before, so the places for entertaining like restaurants and cinemas are all closed. The global trade and economic system have undergone the most serious "stop" since World War II. There have been many people who study the development of stock market and GDP growth the past, but few people make study on this year's stock market. Why it hasn't fallen much as the GDP? Few people have worked on this topic. There are several passages on the newspaper about the stock market this year. Most of them were written in February or March at the time of low stock price in this year, but didn't put the current statistics. This paper summarizes the former research and add the current statistics to show the reasons for the stock price didn't fall a lot during the pandemic.

\subsection{The Economy Situation Under the Epidemic}

\subsubsection{Effects on GDP}

The global economy was largely affected by the pandemic. I only focus on China in this part to show that how the virus affected the GDP.

From the prospective of consumption, China's economy was affected the most during the Spring Festival (from the end of January to February). The consumption expenditure was 5213 billion yuan in the first 2 months, which decreased by $20.5 \%$ compared with the same period of the previous year. [1] After the Spring Festival, many businesses still cannot return to work and some businesses which return to work didn't have as many consumers as before since people are encouraged to stay at home.

From the investment side, affected from the prevention of the spread of the virus, the normal resumption time in more than $90 \%$ of the provinces delayed by 7 work days. Investment in manufacturing, real estate and infrastructure has stalled across the board.

When it is difficult to operate smoothly due to various reasons, most enterprises still need time to return to normal production level. Therefore, it is 
inevitable that the growth rate of fixed assets investment in the whole society declined in the first quarter of 2020.

From the prospective of foreign trade, because of the closing of many factories during the pandemic, the supply of numerous goods was stopped. Besides, during the pandemic, many traffic lines stop to work, for example, the flights to foreign countries. Both export and import are reduced significantly. Comparing the export with import, it is not difficult to find that the export's decreasing proportion is larger than the import. So, trade deficit increased.

On the one hand, the pandemic consumes real social wealth. On the other hand, it creates GDP at the same time. The government spending increased a lot in this period. Also, the production of masks, protective cloth and other medical equipment increased during the epidemic. It was estimated that the output value will reach 7.882 billion yuan by the end of 2020, accounting for $59.78 \%$ of the total output value of the global mask industry.

Figure 1 shows the GDP growth rate in the first quarter in 2020 and the past 3 years. It is very notable that the GDP fell dramatically during the pandemic.

$\mathrm{Y}=\mathrm{C}+\mathrm{I}+\mathrm{G}+\mathrm{X}-\mathrm{M} \quad(\mathrm{Y}=\mathrm{GDP} \quad \mathrm{C}=$ Consumption $\mathrm{I}=$ Investment $\mathrm{G}=$ Government spending $\mathrm{X}=$ exports $\mathrm{M}=$ imports). The consumption, investment and the difference value between export and import all reduced, so the GDP fell sharply in the first quarter.

Table 1: China's year-on-year GDP growth rate (\%) in the first quarter [2]

\begin{tabular}{|l|l|l|l|}
\hline 2017 & 2018 & 2019 & 2020 \\
\hline 7.0 & 6.9 & 6.4 & -6.8 \\
\hline
\end{tabular}

However, this doesn't mean that the whole year's GDP will be very low. The GDP growth rate for second quarter is $3.2 \%$. The GDP for the second quarter grew by $11.5 \%$ from the first quarter. Though the year-on-year growth compared to the same time last year is much lower than before, it shows that the economy was recovering. There are scholars' model forecasts saying that in 2020, the contribution of consumption to China's economy will decrease by $0.8 \%$, the contribution of net export will decrease by $0.7 \%$, and the contribution of investment will increase by $1 \%$. The model estimated that overall GDP growth rate will be $5.6 \%$ in 2020 , which is 0.4 percentage points lower than the normal value, but the economy will not plunge [3].

\subsubsection{Effects on Development of Industry}

The economy growth rate in the first quarter, the primary industry, the secondary industry and the tertiary industry decreased by $3.2 \%, 9.6 \%$ and $5.2 \%$ respectively compared to the same time in 2019. From the given statistics, accommodation and catering industry was affected the most. Construction businesses in the secondary industry was also largely affected. See the agriculture field sin primary industry, because of the lack of workers, the spring ploughing was obstructed. Besides, it is reported that the origin of the virus came from wild animals, which affected the consumption of animals. The feeding industry of the animals such as wild boar and guineas pig was hit heavily. What's more, due to the lack of workers and the transport regulation, some vegetables and fruits cannot be sold to consumers. This caused a large amount of waste. The movie industry, for example, is one of the industries which was affected the most during the pandemic. Most cinemas were closed for more than half a year because of the regulation to avoid contact.

\subsection{Stock Market under the Pandemic}

\subsubsection{Some other cases of stock price during the epidemic}

The S\&P 500, which has the full name of standard pull 500 index, is a stock market index that measures the stock performance of 500 large companies listed on the stock exchange in the United States.

From 1917 to 1920, Spanish flu was brought to Europe by the Americans. The stock market of the United States experienced a big shock from 1919 to 1921. But actually, the fall was largely because of the sequelae of the World War I and Spanish flu does not appear to have a significant impact on US stocks.

Asian flu (1957-1958) and Hong Kong flu (1967-1968) both didn't affect the US stock market significantly.

SARS broke up in 2003, and the U.S. stock market bottomed out in October 2002, followed by the next bottom in April 2003. On the contrary, China's stock market rebounded in April 2003, and continued to decline for half a year, and then rebounded. Finally, it fell sharply in 2005 and bottomed out in June. [4] 


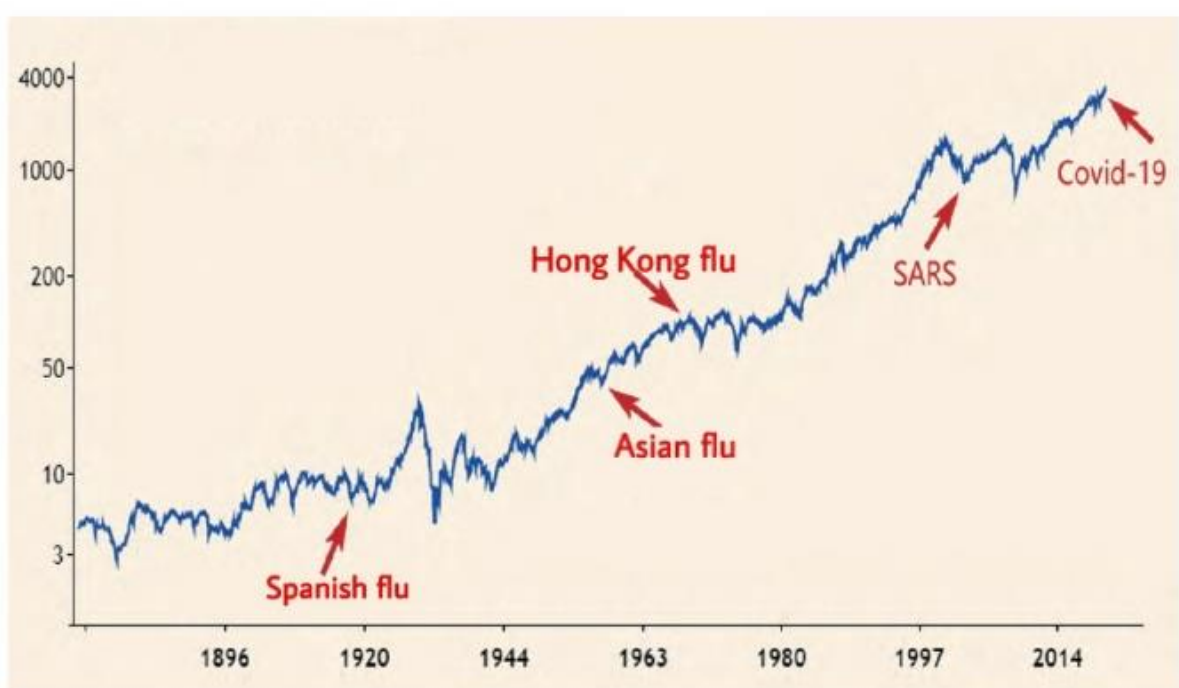

Figure 1. S \& P 500 index trend chart

\subsubsection{Stock market under the situation of coronavirus}

Although the epidemic continues to spread around the world and the number of newly diagnosed cases remains at a high level, the impact of the epidemic on the stock index in the near future seems to be getting smaller from the global stock market. NASDAQ composite index fell to the bottom at 6860 in March and it has repeatedly reached record high, breaking through 10000 points, which is at the highest level in history.[5]

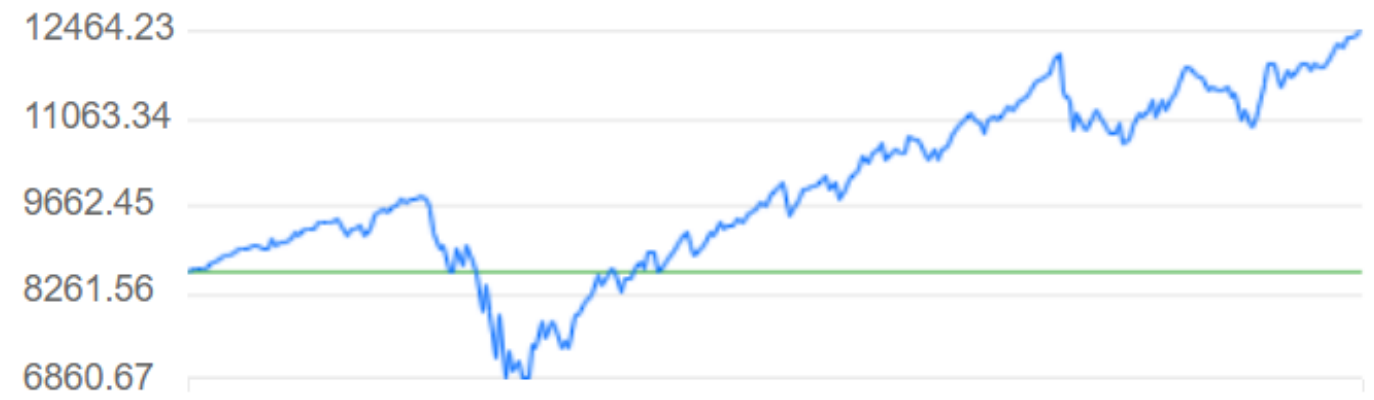

$2019 / 12$

Figure 2. NASDAQ composite index within a year

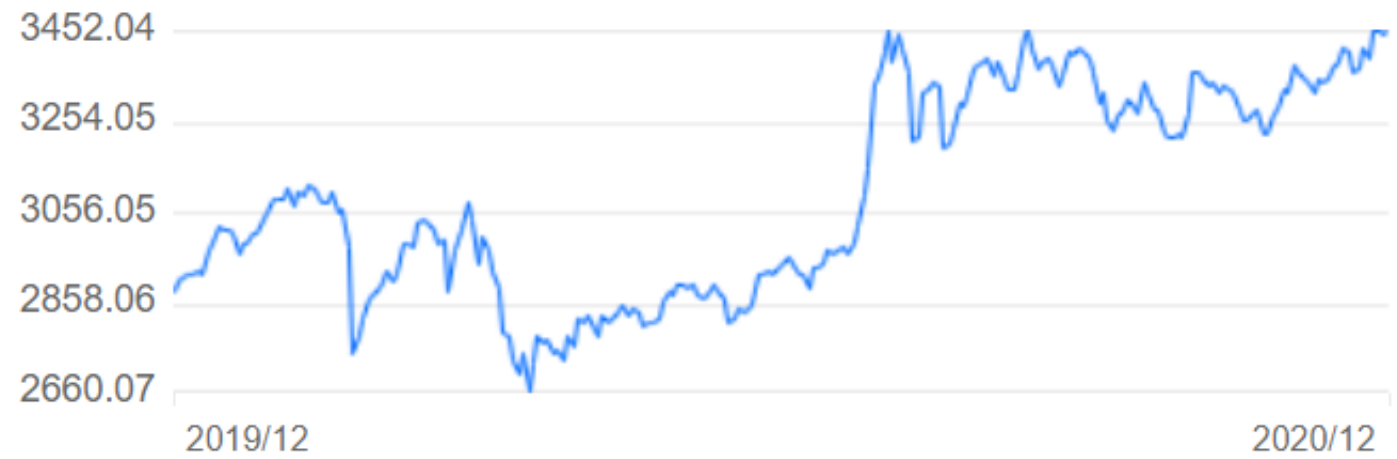

Figure 3. Shanghai (securities) composite index

In 2020, the opening of the market was delayed after spring festival, China's stock market fell after the opening in the short term, and then continued to rise. 


\subsection{Why Stock Price did not Fall as Much as Gdp-Based on the Influence Factor of Stock Market}

\subsubsection{The influence factors of the stock market}

\subsubsection{GDP}

GDP reflects the economy situation of a country. When it falls, it shows that economic depression in the country. Most of the enterprises' operating profit is unprofitable, so enterprises reduced investment to reduce the costs. Because of the economic depression, people's expectation for future income decreased, so the investment decreased. The demand curve for stock moves leftwards so the stock price falls. By contrast, when a country's economy growing very fast and has high level of GDP, the stock price rises as well. There is positive correlation between the GDP and stock price.[6]

\subsubsection{Interest rate}

With the increase of interest rate, the opportunity cost of stock investment becomes larger, capital flows out of the stock market, and the demand is lower than the supply, so there is a slip in stock price. However, when the interest rate falls, the borrowing cost for companies falls, and the expected dividend increase, so the stock price will rise.

\subsubsection{Money supply}

When the central bank implements easy monetary policy, people hold more money, but the investment return of unit currency decreases. The money held by people will exceed their daily needs, and as a result, some currencies are put in the stock market, which leads to a rise in stock price. On the other hand, when the money supply decreases, the interest rate will increase and the investment will decrease, so the stock price will decrease as the result.

\subsubsection{People's confidence and expectation}

When people have the expectation for the future, the believe that the stock price will rise in the future. So, they buy more stocks, which pull the demand curve rightwards so the stock price will rise. During the pandemic, most people have the confidence that we can fight out the corona virus because of the modern technology and the development of medical care, so the stock market is still rising.

\subsubsection{Why stock market did not fell a lot in under the situation of the coronavirus}

During the pandemic, banks decreased the interest rate and increased the money supply, which is good for the stock market. Besides, most people have the confidence that we can fight out the corona virus because of the modern technology and the development of medical care. With these factors, we can know that why so the stock market didn't fell much with the influence of coronavirus even though GDP fell sharply.

What is more, there are different kinds of stocks. Stock price of medical equipment and e-commerce companies even rose during the pandemic because of the rising demand for medical equipment and online shopping.

\section{CONCLUSION}

The global economy was largely influenced by the epidemic and the GDP fell significantly. However, the stock price didn't fell so much and most stock has recovered from low prices. By analyzing few cases before, we can find that actually the impact of major epidemic on the stock market is momentary. Also, because of the development of modern medical treatment, people have the confidence to overcome the impact of the virus, the stock price didn't fall constantly.

\section{ACKNOWLEDGMENT}

First and foremost, I would like to show my deepest gratitude to my teachers and professors in the program for the topic of "Financial Crisis from Subprime Crisis to Coronavirus Crisis", who provided me with knowledge and guidance in writing this thesis. Further, I would like to thank all my friends and families for their encouragement and support. Without their help, I could not have completed my thesis.

\section{REFERENCES}

[1] Chinese government. (2020) Total retail sales of consumer goods will decrease by $20.5 \%$ from January to February 2020. http://www.gov.cn/xinwen/2020-03/16/content_54 91847.htm

[2] National Bureau of Statistics.(2020) Preliminary accounting results of GDP in the first quarter of 2020

http://www.stats.gov.cn/tjsj/zxfb/202004/t2020041 7_1739602.html

[3] W.L. Li, Comparison of coronavirus pneumonia and SARS and its impact on China's economy, First financial daily,2020-02-05(A11). 
[4] L. Wo, The impact of 2020 epidemic on the stock market is limited,2020(04):12-14.

[5] F.Y. Tang, The short-term effect of global stock market affected by the epidemic is getting smaller and smaller, China Economic Times, 2020-07-21(002)

[6] Z.J. Zeng, Z.Jiang, A Study on the effect of macro economy on the stock price,2007(01):40-45. 